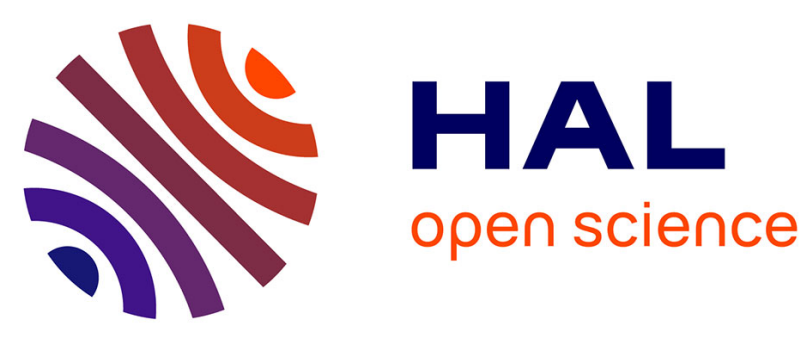

\title{
Romani Syntactic Typology
}

Evangelia Adamou, Yaron Matras

\section{To cite this version:}

Evangelia Adamou, Yaron Matras. Romani Syntactic Typology. Yaron Matras; Anton Tenser. The Palgrave Handbook of Romani Language and Linguistics, Springer, pp.187-227, 2020, 978-3-030-281045. 10.1007/978-3-030-28105-2_7. halshs-02965238

\section{HAL Id: halshs-02965238 https://shs.hal.science/halshs-02965238}

Submitted on 13 Oct 2020

HAL is a multi-disciplinary open access archive for the deposit and dissemination of scientific research documents, whether they are published or not. The documents may come from teaching and research institutions in France or abroad, or from public or private research centers.
L'archive ouverte pluridisciplinaire HAL, est destinée au dépôt et à la diffusion de documents scientifiques de niveau recherche, publiés ou non, émanant des établissements d'enseignement et de recherche français ou étrangers, des laboratoires publics ou privés. 
Romani syntactic typology

Evangelia Adamou and Yaron Matras

1. State of the art

This chapter presents an overview of the principal syntactic-typological features of Romani dialects. It draws on the discussion in Matras (2002, chapter 7) while taking into consideration more recent studies. In particular, we draw on the wealth of morphosyntactic data that have since become available via the Romani Morpho-Syntax (RMS) database. 1 The RMS data are based on responses to the Romani Morpho-Syntax questionnaire recorded from Romani speaking communities across Europe and beyond. We try to take into account a representative sample. We also take into consideration data from free-speech recordings available in the RMS database and the Pangloss Collection. In addition, our chapter is informed by universal studies in syntactic typology, as represented by the entries of the World Atlas of Language Structures (WALS), and other selected typological work.

Matras (2002, chapter 7) covers in comparative perspective prominent features of Romani syntactic typology, including linear order in the noun phrase, constituent order in the verb phrase, possession and external possession, and complex clauses. Since then, only a small number of studies have considered specific topics in Romani syntactic typology in comparative perspective: Elšík and Matras (2006) devote chapters to 
modality, (morphological) case roles, and localization (the lexico-grammatical expression of spatial relations). Elšík and Matras (2009) discuss modality categories, while Matras and Tenser (2016) provide an overview of complementation. Tenser's (2016) discussion of semantic map borrowing in Northeastern Romani dialects is perhaps an isolated study of a syntactic-typological topic in a particular dialect group. In addition, consideration is given to syntactic-typological categories in a number of descriptive studies of individual dialects that have followed Matras (2002), among them Tenser (2005) on Lithuanian Romani and Tenser (2008) on the Northeastern dialects, Leggio (2011) on Mitrovica Romani, Arvaniti and Adamou (2011) and Adamou (2016) on Greek Thrace Romani, Adamou (2013) on Mexican Vlax, Bodnárová (2015) on Vend Romani, Leggio and Matras (2017) on Kangljari Romani, and Benišek (2017) on a North Central Romani 'diaspora' variety spoken in Ukraine.

\section{The noun}

In this section, we discuss linear order in the noun phrase, the prepositional phrase, and the possessive noun phrase, as well as agreement.

\subsection{The noun phrase}

The Romani noun phrase (NP) has four prenominal slots. Quantifiers such as 'all' and 'every' occupy the first slot. A number of determiners that typically do not combine with one another occupy the second slot: demonstratives, definite and indefinite articles, and possessive determiners such as 'my'. Numerals occupy the third slot, and descriptive adjectives the fourth, immediately preceding the noun. Demonstratives, 
possessive determiners and descriptive adjectives can (in some dialects) optionally follow the noun. Figure 1 illustrates the linear order within the Romani NP (adapted from Matras 2002).

Figure 1. Linear order in the NP

$[$ quantifier $]+[$ determiner $]+[$ numeral $]+[$ adjective $]+$ NOUN $+[$ options $]$

Most Romani dialects have a four-term system of demonstratives which distinguishes reference to the discourse context vs. the speech situation (a distinction that only partly corresponds to proximal vs. distal in physical space), and +specific vs. specific (Matras 2002, pp.103-104). Some dialects exhibit a reduced two-term system (for example Sinti Romani). Demonstratives generally inflect for gender, number, and case, and typically precede the noun (DEM-N). The prenominal position is illustrated in (1) from Czech Vlax.

(1) Czech Vlax, Czech Republic (RMS, CZ-001, 386)

kadi angrustji anda somnakaj-i this.NOM.F ring from gold-is

'This ring is made of gold.'

In addition, demonstratives may follow the noun (N-DEM). This option is reported for some RMS dialects from Romania such as Ursari, Spoitori, Kurturare, Kangljari/Peptenari. In this case, however, the definite article is required (the article remains in the prenominal position), e.g., Spoitori o skaunos kaka (the chair this) 'this 
chair; or Sofades Romani (Greece) i romni adaja (the woman this) 'this woman' (example 3 below).

The definite article always precedes the noun (ART-N), as in (2a) from Sofades Romani. Some dialects show reduction or a loss of the definite articles as a result of contact with languages that have no definite articles, as in (2b) from the Polska Roma dialect spoken in Poland, (2c) from a Lovari variety spoken in Russia, and (2d) from Finnish Romani:

(2) 'I couldn't open the door.'

(a) Sofades, Greece (RMS, GR-004, 419)

$\begin{array}{llll}\text { nasti } & \text { putravas } & \mathrm{i} & \text { porta } \\ \text { cannot } & \text { open.1SG.REM } & \text { DEF.OBL.F } & \text { door }\end{array}$

(b) Polska Roma, Poland (RMS, PL-003, 419)

$\begin{array}{llllll}\text { me } & \text { na } & \text { mogindžom } & \text { te } & \text { phiravel } & \text { vudara } \\ \text { I } & \text { NEG } & \text { can.PST.1SG } & \text { COMP } & \text { open.INF } & \text { door }\end{array}$

(c) Lovari Čokeši, Russia (RMS, RUS-005, 419)

$\begin{array}{llll}\text { mə } & \text { naštyk putros } & \text { udar } \\ \text { I } & \text { cannot open.1SG.REM door }\end{array}$

(d) East Finnish Romani, Finland (RMS, FIN-002, 419)

me na vojuvā firavel fūtar 
I NEG can.1SG open.INF door

In most Romani dialects, demonstratives and definite articles cannot form combinations. However, in Romani dialects of Greece, combinations are possible, under Greek influence (Igla 1996, p.165). In (3) from Sofades, a demonstrative precedes the article (DEM-ART-N), and another follows the noun (ART-N-DEM).

(3) Sofades, Greece (RMS, GR-004, 422)

$\begin{array}{llr}\text { adaj } & \text { i } & \text { čhaj } \\ \text { this.NOM.F } & \text { DEF.NOM.F } & \text { girl } \\ & & \\ \text { i } & \text { romni } & \text { adaja } \\ \text { DEF.NOM.F } & \text { woman } & \text { this.NOM.F }\end{array}$

$\begin{array}{lll}\text { therela } & \text { trine } & \text { čhaven } \\ \text { has.3SG } & \text { three.OBL } & \text { children.OBL.PL }\end{array}$

'This girl, this woman, has three children.'

Romani shows an indefinite article, used with singular nouns, derived from the numeral jek/ekh/ek 'one', grammaticalized to various degrees (Matras 1994; Friedman 2001). Example in (4) shows the indefinite article in Vlax Romani from Greece accompanying the presentation of a new participant. Example (5) illustrates the indefinite article with a non-referential noun. Adamou (2016, p.158) notes that in this Romani variety the indefinite article is not used with generic nouns, representing the highest level of grammaticalization. 
(4) Xoraxane, Greece (Pangloss Collection, doi.org/10.24397/pangloss-0000297\#S1)

ek xoraxni sas kxamni

INDF Turkish_woman was.3SG pregnant

'A Turkish woman was pregnant.'

(5) Xoraxane, Greece (Pangloss Collection, doi.org/10.24397/pangloss-0000297\#S10)

mangav phenel ek romni

$\begin{array}{llll}\text { want.1SG } & \text { says.3SG } & \text { INDF }\end{array}$

'He says: I want a woman.'

Like definite articles, indefinite articles too are lost in some dialects (such as Polish and Russian Romani) due to contact.

Romani numerals and quantifiers precede nouns (NUM-N, QNT-N). This order is illustrated in (6) for the numeral 'two', and in (7) for the quantifier 'many'.

(6) Kalderaš, Romania (RMS, RO-065, 477)

si ma duj peha

is me.OBL two sisters

'I have two sisters.' 
(7) Mečkari, Albania (RMS, AL-001, Txt)

ka to aven but manuša andre

COMP COMP come.3PL many men inside

'So that many people can get in.'

Adjectives that express a descriptive property, such as 'big', 'good', or 'red', precede the nouns (ADJ-N). This is illustrated in (8) for the adjective 'big' in Mexican Vlax. However, speakers can also postpose adjectives as afterthoughts (Matras 2002, p.167); this is the case in various RMS samples from Romania, including Vlax, Sinti, and Romungro, as well as in Vlax dialects in other countries (Czech Republic, Mexico, and Ukraine), Lombard Sinti, as well as in some samples from the Balkans, including Albania, Macedonia, and Serbia. The N-ADJ order is illustrated in (9) for Mexican Vlax, using the same adjective, 'big'. (Note that variation in the placement of the adjective is also found in the current contact language, Spanish, associated with differences in meaning or in the degree of evaluation).

(8) Mexican Vlax, Mexico (RMS, MX-001, 593)

o dat katar šavořo sas les ek bari šoro

DEF father from boy was him.OBL INDF big beard

'The boy's father had such a big beard.'

(9) Mexican Vlax, Mexico (RMS, MX-001, 908)

jek žukel baro daravel le cinořen

INDF dog big frighten.3SG DEF children.OBL.PL

'A big dog frightens the children.' 
Unlike in Mexican Vlax, in some dialects postnominal adjectives only occur with doubling of the definite article, e.g., in Agia Varvara Vlax in Greece: $i$ čhej $i$ bari (the girl the big) 'the big girl', replicating the Greek model (Igla 1996, p.166). Whereas in Romani determiner spreading requires a postnominal adjective, in Modern Greek it can occur with both a prenominal or postnominal adjective (Kolliakou 2004).

\subsection{Prepositional phrase}

Romani has prepositions, as commonly found in other Indo-European languages spoken in Europe, whereas postpositions are dominant in Modern Indo-Aryan languages of the Indian Sub-Continent:

(10) Sofia Erli, Bulgaria (RMS, BG-024, 644)

$$
\begin{array}{llllll}
\text { o } & \text { lil } & \text { si } & \text { upral } & \text { i } & \text { masa } \\
\text { DEF letter is on } & \text { DEF table }
\end{array}
$$

'The letter is on the table.'

\subsection{Possessive noun phrase}

The locus of marking in the possessive noun phrase is on the dependent (possessor), not on the head of the phrase (possessed noun). The order of the genitive adnominal (possessor) in relation to the head noun (possessed) is typically GEN-N, the genitive preceding the noun it modifies. Romani adnominal genitives can serve to identify the referent that is expressed by the head noun; they are dubbed 'anchoring' genitive 
adnominals (Koptjevskaja-Tamm 2000, p.126). Anchoring genitive adnominals are used among others for kinship, as illustrated in (11), body parts, as in (12), and ownership, as in (13). Genitive adnominals in Romani can also serve to qualify the head noun, for example, to express quality, age, duration, or material, as illustrated in (14). These are the so-called 'non-anchoring' genitive adnominals. Koptjevskaja-Tamm (2000, p.145) stresses that anchoring genitive adnominals are closer to nouns, as they involve reference, whereas non-anchoring genitive adnominals show lower degrees of similarity with nouns as they are non-referential.

(11) Czech Vlax, Czech Republic (RMS, CZ-001, 594)

$\begin{array}{lll}\text { koda-j } & \text { šāv-esk-i } & \operatorname{dej} \\ \text { this.NOM.F-DEF.NOM.F } & \text { boy-GEN.M-NOM.F } & \text { mother }\end{array}$

sas lāši taj kamaratska

was nice.F and friendly

'The boy's mother was nice and friendly.'

(12) Czech Vlax, Czech Republic (RMS, CZ-001, 600)

$\begin{array}{llr}\text { e } & \text { rom-esk-o } & \text { šejro } \\ \text { DEF.OBL.M } & \text { man-GEN.M-NOM.M } & \text { head }\end{array}$

$\begin{array}{llll}\text { sas tejle } & \text { šaradoj } & \text { kolopo-sa } \\ \text { was down } & \text { cover.GER hat-INS }\end{array}$

'The man's head was covered with a hat.' 
(13) Czech Vlax, Czech Republic (RMS, CZ-001, 511)

jekhe šāv-esk-o gad sas šingerdo

one.OBL boy-GEN.M-NOM.M shirt was cut

'One boy's shirt was torn.'

(14) Kalajdži, Bulgaria (RMS, BG-007, 841)

kindem galben-osk-o koro

buy.PST.1SG gold-GEN.M-NOM.M bracelet

thaj ka dav les məndrə dija-ke

and FUT give.1SG it.OBL my.OBL mother.OBL.F-DAT

'I bought a golden bracelet that I will give to my mother.'

As these examples show, possessors in the genitive case agree with the possessed head noun in number, gender, as well as in case, here in the nominative. Romani thus offers a typologically interesting example of 'double case' or 'Suffixaufhname' (Payne 1995; Plank 1995). These examples further illustrate that determiners, such as articles, demonstratives, and numerals, can determine the possessor. For example, the definite article $e$ in (12) is in the oblique case, agreeing with the genitive case of the possessor 'man'. In (11), however, the demonstrative, kodaj 'this' agrees with the possessed head noun in gender and case, a type of agreement noted by Koptjevskaja-Tamm (2000, p.130) as a breakdown of the traditional system. In some Romani dialects, the genitive may appear in the postnominal position (N-GEN) with more or less high frequency (this option is reported in RMS samples from the Balkans, including Albania, Bulgaria, Greece, Macedonia, Romania, and in some 
samples from Serbia, but also in Molise Romani, Crimean Romani, Eastern Rumungro, and two samples from Ukraine). In this case, a definite article determines both the head noun and the genitive. This is illustrated in (15) with an example from Sofades Romani, a variety in contact with Greek that shares a similar pattern, i.e., o pateras tu ayorju (DEF.NOM.SG.M father.NOM.SG.M DEF.GEN.SG.N boy.GEN.SG.N) ‘the boy's father'.

(15) Sofades, Greece (RMS, GR-004, 593)
o dat i čhav-esk-o
DEF.M father DEF.OBL.M boy-GEN.M-NOM.M

thelas but bare čhora
had.3SG.REM very big.PL beard
'The boy's father had such a big beard.'

In some dialects, the postnominal order is preferred for compounds in non-anchoring function, e.g., in Lovari kher le dil-eng-o (house DEF.OBL.PL crazy-GEN.PLNOM.M) 'mental institution'. These kinds of genitive adnominals are compatible with definite articles, e.g., o kher le dilengo (DEF.NOM.M house DEF.OBL.PL crazyGEN.PL-NOM.M) 'the mental institution'.

\subsection{Agreement}

Romani nominals inflect for case, gender, and number. Definite articles, demonstratives, adjectives, and genitive adnominals inflect for case, gender, and 
number, whereas indefinite articles only inflect for case. Romani has a relatively large case inventory, with 6-7 case types in the sense of Iggesen (2013, WALS 49): it has an (unmarked) nominative, an independent oblique, as well as dative, ablative, locative, genitive, and instrumental (which attach to the oblique case; see Elšík, this volume). As many other Indo-European languages, Romani is a language with two genders; following Corbett (2013, WALS 30) we consider a language to have a gender system when there are different agreement patterns with the verb, adjective, numeral, or determiner:

(16) Arli, Macedonia (RMS, MK-003, 593)

bari brada

big.NOM.F beard

'a big beard'

(17) Arli, Macedonia (RMS, MK-003, 908)

baro džukeł

big.NOM.M dog

'a big dog'

Gender agreement is neutralized in the plural of adjectives. Gender loss is ongoing in some Romani dialects due to contact with languages with no gender distinction, as in Finnish Romani: In (18), genitive caiesko in -o (originally masculine) accompanies the head noun 'father' (masculine), while in (19), the same form appears with 'mother' (feminine): 
(18) Finnish Romani, Finland (RMS, FIN-002, 596)

cai-esko tāt cinjas ta peres nevo pēres

girl-GEN father buy.PST.3SG this year new car

'The girl's father bought a new car this year.'

(19) Finnish Romani, Finland (RMS, FIN-002, 597)

cai-esko taieha sas hyök sonatiko angrusti

girl-GEN mother was beautiful golden ring

'The girl's mother had a beautiful gold necklace.'

3. The verb

\subsection{Alignment}

Following Malchukov, Haspelmath, and Comrie (2010), we distinguish three types of constructions involving a verb: intransitive constructions comprise a single argument (S). Mono-transitive constructions comprise an agent or agent-like argument (A) and a patient or patient-like argument (P), traditionally referred to as an object. Ditransitive constructions consist of a (ditransitive) verb, an agent argument (A), a recipient-like $\operatorname{argument}(\mathrm{R})$, and a theme argument $(\mathrm{T})$. At the notional level, the $\mathrm{R}$ argument would correspond to what is traditionally known as an indirect object, and the $\mathrm{T}$ argument to a direct object.

Most Romani dialects display what Malchukov, Haspelmath, and Comrie (2010) identify as neutral alignment $(\mathrm{A}=\mathrm{S}=\mathrm{P})$ in most clauses, alongside what is identified as 
accusative alignment $(\mathrm{A}=\mathrm{S} \neq \mathrm{P})$ in 'indexing' (agreement or person cross-reference) and 'flagging' (adpositional marking) with animates; see more details in section 6. In ditransitive constructions, alignment is neutral when considering 'ordering' (word order) and 'indexing' $(T=P=R)$, though it is indirective in 'flagging' $(T=P \neq R)$. In sum, Romani does not rely on word order to encode the functions of core arguments. Rather, information structuring determines word order in the verb phrase.

3.2 Word order in main clauses

Most Romani dialects exhibit what can be classified as a thetic-categorical distinction in word order patterns (cf. Sasse 1995; Matras 1995): Categorical predications, or those that pick up a topical category as the perspective of the utterance, tend to show the subject in pre-verbal position. This is exemplified in (20), where Speaker A introduces the topical entity 'The Bajaša' (the Beash people) in a question. Speaker B then picks up the same as a topic entity to answer the question in the following turn in an adjacency pair:

(20) Kurturare, Romania (RMS, RO-015, Txt)

Speaker A:

$\begin{array}{llllll}\text { Vi } & \text { e } & \text { Bajaša } & \text { žan } & \text { po } & \text { kris? } \\ \text { also } & \text { DEF.PL } & \text { Bajaša } & \text { go.PL } & \text { to.DEF.M } & \text { court }\end{array}$


Speaker B:

Le Bajaša či žan, le Bajaša marən pe

DEF.PL Bajaša NEG go.PL DEF.PL Bajaša fight.PL REFL

Speaker A: 'Do the Bajaša also go to kris [Romani court]?'

Speaker B: 'The Bajaša do not go, the Bajaša fight.'

Thetic constructions, on the other hand, do not rely on picking up a single argument as a predication base but instead on the situation as a whole. This is indicated through verbsubject (VS) word order. VS order is often used in presentational constructions to introduce new topics into a narrative setting:

(21) Nea Smirni, Greece (RMS, GR-032, Txt)

aviljo othe lako čhavo kata xorafi

came.3SG.M there her.M boy from field

'Her boy came there from the fields...'

Another frequent function of VS order is consecutive, where the predication is introduced as an immediate consequence of the preceding one:

(22) Lovari (Matras 1994, p.117)

(a)

Vi mure papos avile line anda

also my.OBL grandfather.OBL come.PST.3PL took.PST.3PL from 
DEF.OBL.M house beat.PST.3PL him.OBL

'They came and picked up my grandfather too, they beat him.'

(b)

Taj gelas lesko káko taj počindas vareso bare bare and went.3SG his.M uncle and pay.PST.3SG something big.PL big.PL

love taj kindas les avri.

money and buy.PST.3SG him.OBL out

'And (so) his uncle went and paid a lot of money and bought him free.'

(c)

Taj muri mami garádžulas

and my.F grandmother hide.3SG.REM

$\begin{array}{llll}\text { ande } & \text { veša } & \text { mure } & \text { dadesa. } \\ \text { in.PL } & \text { woods } & \text { my.OBL.M } & \text { father.INS }\end{array}$

'And my grandmother was hiding in the woods with my father.'

The event portrayed in (22b) is presented as the outcome of the preceding state of affairs; this is indicated through VS order. In (22c), we then have a new perspective, introduced by anchoring the predication around a different topical entity. Here, SV order occurs. 
These discourse-pragmatic functions allow making some general predictions about the occurrences of SV and VS, which relativize the impression of free or extremely flexible word order rules. Arguably, there are also additional factors that play a role in the choice of word order, most notably the choice of particular types of predicates and subjects. Igla (1996, p.153) suggests that VS is the unmarked word order when the subject is inanimate, non-determined, and a non-agent, the variant SV being restricted to a (contrastive) emphasis of $\mathrm{S}$. On the other hand, maximum variation is found with subjects that are animate, determined, and which figure as agents. The constraints on variability are thus understood as a continuum (non-agentive animate subjects figuring in between). Predicates that are more likely to trigger VS are those involved in presentative constructions, such as existentials and some verbs of motion, particularly those expressing arrival. Igla (1996, p.151) lists in this connection statements about time and nature (nakhlas ekh beř̌ 'a year passed').

In Romani monotransitive clauses, P-like arguments generally follow the verb, whether they are new or given in the discourse:

(23) Xoraxane, Greece (Adamou 2016, p.176)

lav e lastika

take.1SG DEF.OBL.F hose

'I take the hose.'

P-like arguments may precede the verb for topicalization and focus, generally combining with prosodic marking (Arvaniti and Adamou 2011), as in (24), where the 
focused constituent, 'pills', combines with de-accenting of the postfocal material, in this case the verb.

(24) Xoraxane, Greece (Arvaniti and Adamou 2011, p.243)

me apora peradom

my pills lost.1SG

'I lost my PILLS.'

Fronting of $\mathrm{P}$ arguments is possible in a variety of dialects (reported for RMS samples from Bulgaria, Czech Vlax, Romungro, Finnish Romani, Macedonian Arli, Gabor and Šušuwaje in Romania).

Universally, A-arguments are rarely expressed by full NPs in natural discourse, as noted for several corpora from a variety of languages (Haig and Schnell 2016). In Romani, when A-arguments are expressed by an NP and co-occur with P pronominal arguments, the pronominal $\mathrm{P}$ argument follows the verb:

(25) Erli (Boretzky 1998, p.147)

pale dikhel la thagar

again see.3SG her.OBL DEF.NOM.M king

'The king saw her again.' 
(26) Welsh Romani (Sampson 1926, p.226)

$\begin{array}{llll}\text { kamdias } & \text { les } & \overline{1} & \text { rakli }\end{array}$

love.PST.3SG him.OBL DEF.NOM.F girl

'The girl loved him.'

The typical Balkan 'pronominal object doubling' construction is found in the Balkan and Vlax dialects of Romani (RMS samples from Bulgaria, Moldavia, Romania, Ukraine, as well as in Nea Smirni in Greece, Molise in Italy, and some samples in Serbia and Kosovo). Pronominal object doubling involves exposition of a topical patient, with a co-referential resumptive pronoun in the position following the verb (cf. Bubeník 1997, p.100; see also Friedman 2000):

(27) Sepeči, Turkey (Cech and Heinschink 1999, p.142)

adaja gili da but gilavelas la

this.F song too much sing.3SG.REM her.OBL

'She used to often sing this song too.'

(28) Bugurdži (Boretzky 1993a, p.95)

$\begin{array}{llllll}\text { patózel les } & \text { o } & \text { divi } & \text { e } & \text { romes }\end{array}$

squeeze.3SG him.OBL DEF.NOM.M giant DEF.OBL.M man.OBL

'The giant squeezes the man.'

There is agreement that the construction is not grammaticalised in Romani, but represents a facultative structure triggered at the discourse level (see Boretzky 1993a, pp.94-96; Bubeník 1997, p.102; Friedman 2000, p.197). Friedman (2000) points out 
that unlike the other Balkan languages, Romani preserves a rather complex case declension, and does not have a clear opposition between clitic and non-clitic object pronouns. Both the motivation for object doubling and the structural resources employed in the construction therefore differ.

In Romani ditransitive constructions, with verbs such as 'to give', 'to sell', 'to lend', 'to tell', recipient-like arguments (cf. indirect objects) and theme-like arguments (cf. direct objects) typically follow the verb. In several dialects, nominal R-arguments may precede or follow nominal T-arguments; thus, in most RMS samples from Romania the two orders are equally frequent. TR (or DO-IO) order is possible in Ukraine, possible but not preferred in Sofia Erli and Spoitori, while it is the preferred option in Nea Smirni in Greece. The two word order patterns are exemplified in (29a) and (29b). Similar options are available for pronominal arguments.

(29) 'The priest gives the godmother the baby.'

AVRT

(a) Kalderaš, Serbia (RMS, YU-010, 965)

o rašaj del e čjirv-ja-ke

DEF.NOM.M priest give.3SG DEF.OBL.F godmother-OBL.F-DAT

e cinor-es

DEF.OBL.F baby-OBL.M 
AVTR

(b) Lithuanian Romani, Lithuania (RMS, LT-005/LT-008, 965)

rašaj del čhavor-es bold-e da-ke

priest give.3SG boy-OBL.M baptized-OBL.M mother.OBL.F-DAT

Definite and indefinite animate T-arguments can be fronted or topicalized in a number of dialects, but this is more rarely the case for inanimate $\mathrm{T}$-arguments (coding indicates this possibility in four RMS samples for definite inanimate objects in the accusative; none when they are indefinite). T-arguments can precede verbs when focused, as can be seen in the example in (30). Here the T-argument, 'swipes', combines with the focus-sensitive particle $\mathrm{em}$. The R-argument, the dative pronoun tuke 'to you', remains in the postverbal position.

TVR

(30) Xoraxane, Greece (Adamou 2016, p.179)

em birindzi moromandila daas tuke

FOC first_class swipes give.1SG.REM you.DAT

'I was giving you first-class swipes!'

In the Northeastern dialects, non-topical R arguments appear before the verb, as in example (31) where the dative pronoun tuke 'to you' precedes the verb 'to tell' (see Boretzky 1996b, p.102, Rusakov and Abramenko 1998, p.128). 
TARV

(31) Russian Roma, Russia (RMS, RUS-003, 963)

im'ej $\mathrm{v}$ vidu odova so me tuke rakirav

have in mind that.M what I you.DAT tell.1SG

'You should keep in mind what I tell you.'

3.2 Word order in interrogative and subordinate clauses

In wh-questions, the wh-word appears in clause initial position:

(32) 'What did he give you? Nothing.'

(a) Romungro, Hungary (RMS, HU-009, 385)

so tut dinja? ništa

what you.OBL give.PST.3SG nothing

(b) Lovari, Serbia (RMS, YU-015, 385)

so das tu vo? khanči

what give.PST.3SG you he.NOM nothing

In yes/no questions, a VS order is illustrated for Romungro in (33). Variation between a VS and an SV order is recorded in RMS samples from Velingrad Yerli in Bulgaria, Romungro in Hungary, Molise and Kylmyš in Ukraine, and Katolikurja in Serbia, Gabor, Šušuwaje, Piculesči, and Spoitari from Romania, among other. VS dominant order in yes/no clauses is reported in the RMS samples from Nea Smirni in Greece, Lombard Sinti in Italy, Mexican Vlax, and in most dialects of Romania. 
(33) 'Is the water boiling?'

Romungro, Hungary (RMS, HU-009, 887)

tatjol o pānji?

boil.3SG DEF.M water

In non-factual subordinations, such as purpose clauses, modal complements, and conditional clauses introduced by te, the verb immediately follows the conjunction te. In some dialects, the verb may occupy the final sentence position, in particular through influence from Slavic contact languages. Such uses are reported in the RMS samples from the Balkans (Bulgaria, Greece, Macedonia, Serbia) but also Austrian Sinti, Romungro in Hungary, Molise in Italy, Crimean in Russia, Laeši Kurtej in Moldavia, Kubanska Vlaxurja in Ukraine, and Eastern Rumungro in Slovakia. Examples (34) and (35) illustrate the variation in the position of the verb in a subordinate clause in Romungro, occurring within the same elicitation context.

(34) Romungro, Hungary (RMS, HU-009, 345b)

na kamav ando gav te džan

NEG want.1SG in.DEF.M village COMP go.INF

'I do not want to go to town.'

(35) Romungro, Hungary (RMS, HU-009, 346b)

na kames te džan ando gav

NEG want.2SG COMP go.INF in.DEF.M village

'You do not want to go to town.' 
Sinti varieties show various degrees of convergence with German word order rules. In the most extreme cases, the German distinction between main clause (verb in second position), subordinate clause (verb in final position), and interrogative clause (verb in initial position) is adopted consistently (see Matras 1999b).

Non-factual complement clauses and conditional clauses, both introduced by te, show an overwhelming, if not absolute, tendency toward VS order.

(36) Lovari (Matras 1994, p.225)

amende akana te merel varekon

us.LOC now COMP die.3SG somebody

'Among us, now, if somebody dies ...'

(37) Sinti, Germany (Holzinger 1993, p.163)

me kamoms te vals tu

I want.1SG.REM COMP come.2SG.REM you

'I would have liked you to have come.'

(38) Sinti, Germany (Holzinger 1993, p.156)

te krel miri čaj kova, dan leli daba

COMP do.3SG my.F daughter this then get.3SG.F blows

'If my daughter does this, she will get blows.' 
This rule is not compromised even in those varieties of German Sinti that have adopted German word order and that have the verb in final position in all other subordinate clauses (Matras 1999b). Isolated exceptions to the rule are found however in some of the Central dialects (Boretzky 1996b, p.107), and most systematically in Roman as shown in (39).

(39) Roman (Wogg and Halwachs 1998, p.53)

te me valakaj gejom

COMP I somewhere went.1SG

'If I went somewhere...'

For Sepeči, Cech and Heinschink (1999, p.144) suggest that tendencies towards VS in temporal adverbial clauses, as in (40), may be overridden when $\mathrm{S}$ is focused, resulting in SV, as in (41). Example in (42) illustrates SV order with a pronoun.

(40) Sepeči, Turkey (Cech and Heinschink 1999, p.144)

kana isine o roma ko balanipe

when was DEF.M Rom.PL in Greece

'When the Rom were in Greece...'

(41) Sepeči, Turkey (Cech and Heinschink 1999, p.144)

kana čhaj isinomas

when girl was.1SG

'When I was a young girl ...' 
(42) Xoraxani, Bulgaria (RMS, BG-015, 869)

kana odva asala bütüj kvartal može te

when DEM.M laugh.3SG everyone neighbour can COMP

šunel les

hear.3SG him.OBL

'When he laughs, the whole neighbourhood can hear him.'

Some central European dialects show tendencies towards what Boretzky refers to as a 'split verb frame' (Boretzky 1996b, pp.104-105). This involves the fronting of constituents of the modal quasi-infinitive verb in te-clauses. See examples in (43) from Roman and from Polska Roma in (44).

(43) Roman (Wogg and Halwachs 1998, p.48)

ada berš kezdinčom andi iškola te džal

this year begin.PST.1SG in.F school COMP go.INF

'That year I began to go to school.'

(44) Polska Roma (Matras 1999a, p.19)

taša džasam sare dro veš kašta te čhineł

tomorrow go.1PL.FUT all in forest wood.PL COMP cut.INF

'Tomorrow we will all go to the forest to cut wood.' 
4. Complex clauses

4.1 Relative clauses

In this chapter, we rely on the definition of relative clauses as subordinate clauses that are used to delimit the reference of a NP (Andrews 2007). Almost all Romani dialects in the RMS sample introduce relative clauses with the uninflected complementizers $k a j$ (from $k a j$ 'where'). Most also use the uninflected complementizer so/hoj 'what' to relativize nouns referring to non-humans, but some dialects additionally use them for humans. Some dialects also use the relative pronouns savo 'which' (inflecting for case, gender, and number) and kon 'who' (inflecting for case). As seen in (45), Romani relative clauses are externally headed and postnominal, i.e., the relative clause follows the head noun (NRel). Subject relativizers can follow two 'primary' relativization strategies (Keenan and Comrie 1977): The 'gap strategy' shows a complementizer without explicit coreferentiality with the head noun (45a), while the inflected relative pronoun (45b) shows agreement with the head noun and in this case also an inflected resumptive pronoun:

(45) 'The man who came to the wedding has many new cars/a new car.'

(a) Nea Smirni Romani, Greece (RMS, GR-032, 590)

$\begin{array}{llllll}\text { oduua } & \text { rom } & \text { ka } & \text { avilo } & \text { ko } & \text { bjav } \\ \text { that.M } & \text { man } & \text { COMP } & \text { come.PST.3SG } & \text { to.M } & \text { wedding }\end{array}$


isineh but nava amakši

was many new car

(b) Kaldaraš, Romania (RMS, RO-008, 590)

$\begin{array}{llllll}\text { o } & \text { murš } & \text { savo } & \text { avilo } & \text { kaj } & \text { nunta } \\ \text { DEF.NOM.M } & \text { man } & \text { who } & \text { come.PST.3SG } & \text { to.F } & \text { wedding }\end{array}$

si les mašina nevi

is.3SG him.OBL car new.F

Pronominal resumption in relative clauses may have developed in Early Romani through contact with Greek (Matras 1994, pp. 206-210); it is also available in Modern Greek (Alexopoulou 2006). Case, animacy and definiteness may condition the resumptive strategy, which in many dialects is obligatory with non-nominative subjects.

Examples in (46) and (47) illustrate optional resumption in restrictive relatives. In (46a) the resumptive pronoun carries the case marking for the direct object relative clause. In (46b) there is no resumption, but the head is marked for the oblique (direct object) case.

(46) 'The man that I/we saw yesterday is here (again).'

(a) Kaldaraš, Romania (RMS, RO-008, 809)

o manuš savo dikhljam les arači

DEF.NOM.M man REL see.PST.1PL him.OBL yesterday 
sy pale kačhe

is again here

(b) Nea Smirni Romani, Greece (RMS, GR-032, 809)

i muršes kaj dikhlom i rat isi athe

DEF.OBL.M man.OBL.M COMP see.PST.1SG yesterday is here

Similarly, in (47a), no resumption appears where the relative pronoun saveske inflects for case, while in (47b) resumption carrying case marking accompanies the uninflected using relativizer/complementiser $k a$ :

(47) 'This is the boy who I gave the money to.'

(a) Kaldaraš, Romania (RMS, RO-008, 813)

kadoa sy $0 \quad$ raklo saves-ke dem love

this.M is DEF.NOM.M boy REL.OBL-DAT gave.1SG money

(b) Nea Smirni Romani, Greece (RMS, GR-032, 813)

oduva o čhavo ka dinom leh $\mathrm{o}$ love

this.M DEF.NOM.M boy COMP gave.1SG him.OBL DEF.M money

4.2 Complement clauses

A complement clause functions as a core argument of the matrix verb instead of a NP

(Dixon 2010, pp.370, 380). Typical matrix verbs with complement clauses are epistemic 
verbs, such as 'say', 'see', 'know', and manipulation verbs, such as 'want', 'ask', 'tell'. Modal verbs of a 'secondary semantic type', such as 'begin', verbs expressing mental states, like 'fear', and the impersonal modals of ability 'can', 'cannot' and necessity 'must', also introduce complement clauses. In typological perspective, Romani complement clauses are finite and 'balanced', that is, the verb form follows that of the independent declarative (Cristofaro 2013, WALS 128). Romani complement clauses are introduced by complementizers of the types KAJ and TE (see Matras and Tenser 2016 for a recent overview). KAJ (from 'where') is also used for relative clauses. TE can probably be linked to an Old Indo-Aryan correlative function (Matras 2002, p.180) and also introduces conditional clauses. KAJ introduces complements portraying factual events, with an independent truth-value, whereas TE introduces non-factual or modal events, with no independent truth-value. This mirrors a distinction found in the Balkan languages. Friedman (1985) discusses te in the context of what he calls the 'Dental Modal Subordinator' of the Balkan languages whose primary function is to denote ontologically non-real events (Balkan Slavic $d a$, Albanian të, Romanian să, Greek $n a$ ).

In several dialects, the complementizer KAJ has been replaced by borrowed functional equivalents: Vlax kə/ke from Romanian; Arli and Greek Vlax oti from Greek; Central Romani hod/hodž/hod'/hot/hoj from Hungarian. By contrast, TE is stable, with rare exceptions, e.g., Bulgarian Xoraxani borrows $d a$ from Bulgarian. In some dialects, the complementizer is omitted with uninflected impersonal modals of positive and negative ability 'can' and 'cannot' (see Elšik and Matras 2006, p.206; Matras and Tenser 2016 for more details). Welsh Romani and Istrian/Slovene Romani are the only dialects that have not retained the factuality distinction, but generalise te. 
Examples in (48) illustrate the use of KAJ:

(48) 'They (probably) thought that I was in the pub.'

Arli, Macedonia (RMS, MK-003, 460)

oła najverojatno mislinde kaj injum me ko bari

they probably think.PST.3PL COMP was.1SG I to.M bar

Kalderaš, Serbia (RMS, YU-010, 460)

von gndosardine kaj sem me ando birto

they think.PST.3PL COMP was.1SG I in.M bar

East Slovak, Slovakia (RMS, SK-011, 460)

mišljinde peske hoj som and(r)e karčma

think.PST.3PL REFL.DAT COMP is.1SG in.M bar

TE is used for non-factual events. Agent control and manipulative intent of the agent are relevant aspects in manipulation clauses involving a manipulator (the agent of the modal verb) and a manipulee (the agent of the complement verb) (see Matras 2002; Matras and Tenser 2016). On the hierarchy of control, we find in some dialects a split between the plain use of TE and a combination of TE and a 'reinforcer', often KAJ, in the combination kaj te etc. (see Matras and Tenser 2016), especially with differentsubject manipulation or weak manipulative power or intent: 
(49) 'I want him/her to go away/home.'

(a) Arli, Macedonia (RMS, MK-003, 436)

mangava le te džal peske

want.1SG him.OBL COMP go.3SG REFL.DAT

(b) Kalderaš, Serbia (RMS, YU-010, 436)

me kamav te voj žaltar

I want.1SG COMP she go_away.3SG

(c) East Slovak Romani, Slovakia (RMS, SK-011, 436)

kamav hoj te džal khere

want.1SG COMP COMP go.INF home

(d) Polska Roma, Poland (RMS, PL-018, 436)

kamdomys kej te otdžał juv

wan.PST.1SG.REM COMP COMP go.INF he

(e) Sinti, Romania (RMS, RO-022, 436)

$\begin{array}{lllll}\text { kamau } & \text { ti } & \text { džal } & \text { u } & \text { vek }\end{array}$

want.1SG COMP go.3SG to away 
(50) 'I told her to buy mushrooms, onions and cabbage.'

(a) Arli, Macedonia (RMS, MK-003, 438)

vakerdum lake te kineł pečurke purum hem armin

tell.PST.1SG her.DAT COMP buy.3SG mushrooms onions and cabbage

(b) Kalderaš, Serbia (RMS, YU-010, 438)

me lake phendem te čjinol gljive purum

I her.DAT tell.PST.1SG COMP buy.3SG mushrooms onions

taj šax

and cabbage

(c) East Slovak, Slovakia (RMS, SK-011, 438)

phendžom lake hoj te cinel hubi

tell.PST.1SG her.DAT COMP COMP buy.INF mushrooms

cibulja he jarmin

onions and cabbage

(d) Polska Roma, Poland (RMS, PL-018, 438)

phendom łake te kineł gžyby purom i armen

tell.PST.1SG her.DAT COMP buy.INF mushrooms onions and cabbage 
(e) Sinti, Romania (RMS, RO-022, 438)

phindžjom laki te kinel i šfami

tell.PST.1SG her.DAT COMP buy.3SG DEF.NOM.PL mushrooms

puruma ti šaxa]

onions and cabbage

Manipulation and purpose clauses in Romani generally show similar complementation strategies (see section 4.3).

\subsection{Adverbial clauses}

Romani adverbial clauses are generally finite, that is, the verbs in the subordinate clause are marked for person and number. They are introduced by various adverbial subordinators, which derive from grammaticalised inherited items as well as borrowings, and occupy the initial position in the subordinating clause. Table 1 presents an overview of the Romani adverbial subordinators.

Table 1. Adverbial subordinators in Romani conditional condition (realis and irrealis) te, bi/by, ako, -se, kana, kada, an te

\begin{tabular}{ll}
\hline potential condition ('whether') & te, ob te, či/čy, dali, li, mi \\
\hline concessive condition ('even if') & vi te, nina te, kajk te \\
\hline irrealis concession ('as if') & har/sar te, hata kaj
\end{tabular}




\begin{tabular}{|c|c|c|}
\hline \multirow[t]{3}{*}{ temporal } & simultaneity & $\begin{array}{l}\text { kana, kada/keda, sar/har/syr, } \\
\text { kaj, so, afu }\end{array}$ \\
\hline & anteriority & $\begin{array}{l}\text { sar/syr/har, angla sar, angla } \\
\text { kodo ke, bi te na, prin te }\end{array}$ \\
\hline & posteriority & $\begin{array}{l}\text { kana, kada/keda, sar/har/syr, } \\
\text { kaj, so, posle, čim, pala kodo } \\
\text { ke, akana, jekh kaj, jekh ta }\end{array}$ \\
\hline causal relations & cause, reason, explanation & $\begin{array}{l}\text { kaj, kə/ke, vajl, anda kodo ke, } \\
\text { sostar, soske, sar, adake sar, } \\
\text { sebepi kaj, afu, jati, zere, bo, } \\
\text { mer, jer, lebo, pošto }\end{array}$ \\
\hline purpose & & $\begin{array}{l}\text { te/ti, kaj te, hot te, kə te, ja te, } \\
\text { či te }\end{array}$ \\
\hline other & $\begin{array}{l}\text { negative circumstance } \\
\text { ('without') }\end{array}$ & bi te, oni te \\
\hline
\end{tabular}

Boretzky (1993b) notes that Romani dialects distinguish conditional clauses based on the truth-value of the proposition, in particular, between realis and irrealis, similar to other Balkan languages (cf. Friedman 1985). Examples in (51) illustrate the conditional clauses for realis from the main dialectal groups in the RMS samples. Most conditional clauses are introduced by the subordinator TE. Some dialects exhibit variation with borrowed subordinators such as ako (from Slavic), as in (51b) from the Kalderaš variety, while Polska Roma shows ho 'what', which has been generalized as an adverbial subordinator, in (51d). 
(51) 'If I drink a lot of milk, I will be strong.'

(a) Arli, Macedonia (RMS, MK-003, 423)

te pilum but thud $\mathrm{k}$ ovav but siłno

COMP drink.PST.1SG much milk FUT become.1SG much strong.M

(b) Kalderaš, Serbia (RMS, YU-010, 423)

ako pjav but thud avava zuralo

if drink.1SG many milk become.FUT.1SG strong.M

(c) East Slovak, Slovakia (RMS, SK-011, 423)

te pijava but thud avava zoralji

COMP drink.FUT.1SG many milk become.FUT.1SG strong.F

(d) Polska Roma, Poland (RMS, PL-018, 423)

ho pjava but thud to vava zurało

COMP drink.FUT.1SG much milk CORR become.FUT.1SG strong.M

Examples in (52) illustrate that TE shows greater stability in irrealis conditional clauses, supplemented in some dialects by borrowed conditional particles, as in Eastern Slovak Romani $b i$ in $(52 \mathrm{c})$ : 
(52) 'If you had come yesterday, you would have seen her.'

(a) Arli, Macedonia (RMS, MK-003, 411)

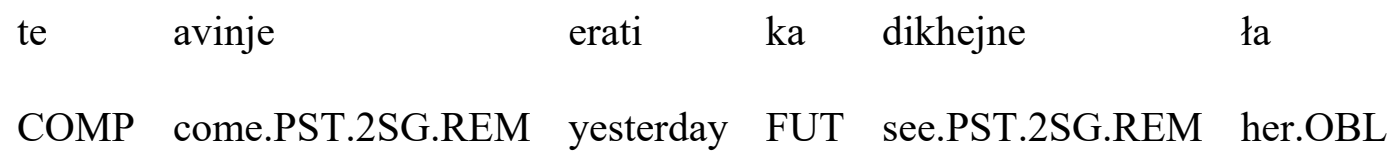

(b) Kalderaš, Serbia (RMS, YU-010, 411)

$\begin{array}{lllll}\text { te } & \text { avilanas } & \text { aračji } & \text { dikhlanas } & \text { la } \\ \text { COMP } & \text { come.PST.2SG.REM } & \text { yesterday } & \text { see.PST.2SG.REM } & \text { her.OBL }\end{array}$

(c) East Slovak, Slovakia (RMS, SK-011, 411)

te bi avehas tajsa ta bi la

COMP COND come.2SG.REM yesterday CORR COND her.OBL

dikhehas

see.2SG.REM

(d) Polska Roma, Poland (RMS, PL-018, 411)

te vjanas tejsa to la dyktanas

COMP come.PST.2SG.REM yesterday CORR her.OBL see.PST.SG.REM

Potential condition ('whether') is often expressed by TE, as in (53c) for Sinti, though as the other examples in (53) show there is a strong tendency to use borrowed particles in this function: 
(53) 'I asked the male teacher whether he is coming to the wedding.'

(a) Arli, Macedonia (RMS, MK-003, 429)

$\begin{array}{llllllll}\text { pučhlum } & \text { e } & \text { učitele } & \text { dali } & \text { ka } & \text { avol } & \text { ko } & \text { bijav } \\ \text { ask.PST.1SG } & \text { DEF.OBL.M } & \text { teacher } & \text { whether } & \text { FUT } & \text { come.3SG } & \text { to.M } & \text { wedding }\end{array}$

(b) East Slovak, Slovakia (RMS, SK-011, 429)

phučljom mire učiteljostar či avela pro

ask.PST.1SG my.OBL.M teacher.ABL whether come.3SG.FUT to.M

bijav

wedding

(c) Sinti, Romania (RMS, RO-022, 429)

bučom 0 profesares te vela pe bijap

ask.PST.1SG DEF.M teacher.OBL.M COMP come.3SG to.OBL.M wedding

General simultaneity 'when' is usually expressed by the subordinator kana, which can also be used for more precise temporal relations such as immediate anteriority ('as soon as') or parallel duration ('while', 'as long as'). In some dialects, specific simultaneity, 'just as', is expressed through a different subordinator, for example sar in (54c) from East Slovak Romani and syr in (54d) from Polska Roma. The temporal domain shows extensive borrowing as can be seen in (54a) for Arli using the Slavic koga. 
(54) 'When I was young, I lived in a big house in a town.'

(a) Arli, Macedonia (RMS, MK-003, 623)

koga injumine terno živindum ko baro kher ki dis when was.1SG young.M live.PST.1SG in.M big.M house in.F town

(b) Kalderaš, Serbia (RMS, YU-010, 623)

kana semas terno traisardem ande jekh baro kher when was.1SG young.M live.PST.1SG in.OBL.M INDF big.M house

ande jekh foro

in.OBL.M INDF town

(c) East Slovak, Slovakia (RMS, SK-011, 623)

sar somas cikno bešavas andro jekh baro kher

how was.1SG young.M live.PST.1SG in.M INDF big.M house

andro foros

in.M town

(d) Polska Roma, Poland (RMS, PL-018, 623)

hyr homys terno to homys andre baro khir

how was.1SG young.M CORR was.1SG in.OBL.M big.M house 
bešjto andre furo

live.PTCP.M in.OBL.M town

Some dialects show two separate conjunctions for anteriority, corresponding to the degree of presupposition: e.g., in Lovari angla kodo ke avilo 'before he arrived', and angla kodo te avel 'before he arrives'. Other dialects assign anteriority ('before') and anterior-durative ('until') to one of the two groups (i.e., dži kaj or dži te for 'until').

Cause, reason, and explanation are expressed with the complementizer KAJ, as in (55b) for Kalderaš, or with case-marked interrogatives, usually in the dative or ablative, such as soske 'because' (lit. 'for-what') in (55a) for Arli, or else with a borrowed conjunction and calquing.

(55) 'I went home because I was tired.'

(a) Arli, Macedonia (RMS, MK-003, 462)

gelum khere soske injumine umorno

went.1SG home what.DAT was.1SG tired.M

(b) Kalderaš, Serbia (RMS, YU-010, 462)

$\begin{array}{lllll}\text { me } & \text { gelem } & \text { khere kaj } & \text { semas hičjino } \\ \text { I } & \text { went.1SG } & \text { home } & \text { COMP } & \text { was.1SG tired.M }\end{array}$

For purpose clauses, most dialects use the complementizer TE. Some dialects combine KAJ or a borrowed functional equivalent with TE as can be seen in East Slovak Romani 
in (56c) and in Polish Romani in (56d). This is often sensitive to degree of control and subject identity across the two clauses:

(56) 'I opened the window so that I can hear you.'

(a) Arli, Macedonia (RMS, MK-003, 443)

phadum žami te šaj te havav tu

open.PST.1SG DEF.NOM.M window COMP can COMP hear.1SG you

(b) Kalderaš, Serbia (RMS, YU-010, 443)

me putardem $\quad$ e $\quad$ feljastra

I open.PST.1SG DEF.OBL.F window

te šaj te ašunav tu

COMP can COMP hear.1SG you

(c) East Slovak, Slovakia (RMS, SK-011, 443)

phundradžom e bloka hoj tut te šunav

open.PST.1SG DEF.OBL.F window COMP you.OBL COMP hear.1SG

(d) Polska Roma, Poland (RMS, PL-018, 443)

phiradom okna kej tot te šjonav

open.PST.1SG window COMP you.OBL COMP hear.1SG 
4.4 Non-finite forms

As illustrated in the previous section, Romani subordinate clauses are predominantly finite. Indeed, an inherited infinitive was most likely lost through contact with Iranian languages and, in particular, through contact with Greek and other Balkan languages, which all exhibit loss of the infinitive. The so-called 'new infinitive' (Boretzky 1996a) that can be noted in several dialects probably emerged after the migration from the Balkans to Northern and Western Europe under the influence of infinitives in the contact languages. New infinitives are found in Sinti, Finnish Romani, Romungro and Romani spoken in Poland, Ukraine and Slovakia. The new infinitive developed from the historical present tense personal markers following loss of person agreement; see (57) for a generalised second person singular form in $-(e) s$ and in $(58)$ for the third person singular in $-(e) l$.

(57) East Finnish Romani, Finland (RMS, FIN-008, 754)

jou pyrjylä ceer-es putti

he begins do-INF work

'He begins to work.'

(58) East Slovak, Slovakia (RMS, SK-002, 345b)

$\begin{array}{llllll}\text { na kamav } & \text { te } & \text { dža-l } & \text { andro foros } \\ \text { NEG } & \text { want.1SG } & \text { COMP } & \text { go-INF } & \text { in.M } & \text { town }\end{array}$

'I do not want to go to town.' 
In a Romani variety from Ukraine, the infinitive has the form of a present subjunctive without the final consonant:

(59) Servi, Ukraine (RMS, UKR-004, 754)

vov ačhel te tire buti

he begin.3SG COMP do.INF work

'He begins to work.'

Romani makes use of gerunds as converbs in -indoj for simultaneity or cause:

(60) Mexican Vlax, Mexico (RMS, MX-001, 961)

rovindoj bešli paša amende

cry.GER sat.F next us.LOC

'Crying she sat down next to us.'

\section{Negation}

Clausal negation in Romani is expressed through verb negators and negative indefinites. The most distinctive feature of Romani verb negators is that they are sensitive to the mood of the verb. Most Romani dialects have separate negators for indicative and nonindicative, while some dialects also have distinct negators for indicative, subjunctive, and imperative clauses.

Most dialects use the negator $n a$ for the indicative, as can be seen for Arli in (61a), East Slovak Romani in (61c), and Polish Romani in (61d). Innovative negators are found in some dialects, for example in the Sinti sample in (61e) we note the use of 


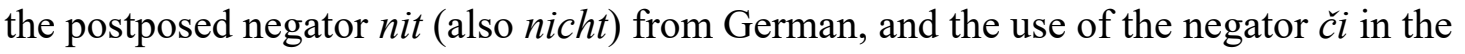
Kalderaš sample in (61b). The independent negator $\check{c} i$ is generally used in Northern Vlax. It probably started as a negative scalar focus particle 'neither, nor, not even' deriving from the indefinite $\check{c} i$, and then became a marker of negative clause coordination, in all likelihood under the influence of Romanian nici ... nici (see Elšík 2000). The negator in is used in Southeastern Vlax (possibly a reduced form of the original negator, later modified through an initial vowel); $n i$ for Southwestern Vlax (possibly a Southern Vlax innovation, which may have merged with the Slavic negators of the surrounding languages ne/nie).

(61) 'I don't know.'

(a) Arli, Macedonia (RMS, MK-003, 344b)

na džanava

NEG know.1SG

(b) Kalderaš, Serbia (RMS, YU-010, 344b)

me či žanav

I NEG know.1SG

(c) East Slovak, Slovakia (RMS, SK-011, 344b)

na džanav

NEG know.1SG 
(d) Polska Roma, Poland (RMS, PL-018, 344b)

na džinav

NEG know.1SG

(e) Sinti, Romania (RMS, RO-022, 344b)

džinau nit

know.1SG NEG

In the imperative, most dialects use $m a$, as shown in (62), for Arli, East Slovak Romani, Polish Romani, and Sinti. In some dialects, as in several Vlax dialects illustrated through the Kalderaš sample in (62b), the negator $n a$ has been extended to the imperative, most likely before its replacement by an innovative negator in the indicative, or has been generalized independent of the mood of the verb, e.g., in Ukrainian Central Romani (Benišek 2017, p.397).

(62) 'Friends, don't get angry (at me).'

(a) Arli, Macedonia (RMS, MK-003, 367)

amałalen ma hołanen

friends.VOC NEG be_upset.IMP.PL

(b) Kalderaš, Serbia (RMS, YU-010, 367)

xanamika na len xoli pe mande

friends NEG take.IMP.PL anger on me.LOC 
(c) East Slovak, Slovakia (RMS, SK-011, 367)

čhavale ma javen xoljamen

friends.VOC NEG become.IMP.PL angry

(d) Polska Roma, Poland (RMS, PL-018, 367)

mire čhave ma denervinen tomenge

my children NEG be_angry.IMP.PL you.2PL.DAT

(e) Sinti, Romania (RMS, RO-022, 367)

mra māla ma aven xojmen

my.PL friends NEG become.IMP.PL angry

In the subjunctive, the negator can be the same as either the indicative or the imperative negator:

(63) 'I (will) shut the window so that he can't hear us.'

(a) Arli, Macedonia (RMS, MK-003, 444)

ka phandavo o žami te na havol amen ov

FUT shut.1SG DEF.M window COMP NEG hear.3SG us he

(b) Sinti, Romania (RMS, RO-022, 444)

kerjom $\quad c u \quad i \quad$ fenstra ma ti šunel $u$ men

do.PST.1SG shut DEF.F window NEG COMP hear.3SG he us.OBL 
Several dialects have a unique negator for the third person copula. In the Arli (MK-003) and East Slovak (SK-011) samples one finds the use of nani/nane. In the Kalderaš sample from Serbia, one can observe the more general Vlax negative copula $n a j<* n a$ hi (NEG is.3SG) (Elšík and Matras 2009).

In Welsh Romani and in some Sinti/Manuš varieties, the indefinite marker kek 'nothing' $(<* k a-j e k h)$ is occasionally used as an independent, postposed negator, e.g., kamelas kek 'he didn't want' (Elšík 2000). In German Sinti, the German particle gar undergoes a similar development, and in some varieties, it serves as the principal indicative negator, e.g., kamom gar 'I didn't want'.

Negative indefinites are prone to renewal processes through internal grammaticalisation and borrowing. Their specialisation as negatives is recent and dialect-specific (Elšík 2000). Negative indefinite expressions in Romani are generally related to indefinites with a positive meaning, though in some cases traces of positive readings appear only marginally (e.g., general Vlax khanči 'nothing', but Agia Varvara Vlax kajši 'something'). One can therefore assume that clause negation relied originally primarily on the verb negator rather than on an indefinite negative. This state of affairs is generally continued in Romani irrespective of the subsequent specialisation of some of the indefinite expressions as negative indefinites.

(64) Polska Roma, Poland (RMS, PL-018, 385)

so jov tu dyja? Čhi

what he you give.PST.3SG nothing

'What did he give you? Nothing.' 
(65) Polska Roma, Poland (RMS, PL-018, 740)

čhi pe na kerdža

nothing REFL NEG do.PST.3SG

'Nothing happened.'

6. Case representation

\subsection{Semantic roles}

Alignment in 'flagging' is nominative-accusative (of the standard type) for the animate arguments. This means that the single argument of an intransitive clause (S) and the agent-like argument (A) of a monotransitive clause are marked with the same case (i.e., nominative), whereas the animate patient-like argument of a monotransitive clause $(\mathrm{P})$ takes a different case, which is more marked than the nominative case. Different authors refer to this case as an 'accusative' or as an 'independent oblique' (see Matras 2002). In contrast, the inanimate $\mathrm{P}$ argument has the same marking as the $\mathrm{S}$ and $\mathrm{A}$ arguments, that is, it exhibits neutral case marking. The different case marking patterns observed in Romani depending on the types of full NP are quite common cross-linguistically (Comrie 2013, WALS 98).

In Romani, the recipient-like (R) argument of verbs such as 'to give' and 'to show' is expressed through the dative case marker; see (66a). However, the independent oblique case may also be used, as exemplified in (66b). 
(66) 'People give the priest some food.'

(a) Lithuanian Romani (RMS, LT-007, 966)

manuša den rašaske nabut xaben

man.PL give.3PL priest.OBL.M.DAT some food

(b) Sinti, Romania (RMS, RO-022, 966)

o manuša den $\quad$ o rašajes $\quad$ xaben

DEF.PL man.PL give.3PL DEF.M priest.OBL.M food

The recipient-like $(\mathrm{R})$ argument for the 'benefactive' and 'goal' roles is expressed mainly through the dative case marker and a preposition, as in the Sinti sample in (67a), and more rarely through the locative case, as in the example from Kalderaš in (67b).

(67) 'He left this food for you (sg) and your brothers.'

(a) Sinti, Romania (RMS, RO-022, 851)

jop mukjas kao xaben vaš tuke ti vaš te

he leave.PST.3SG this.M food for 2SG.DAT and for your.PL

phralenge

brother.OBL.PL.DAT 
(b) Kalderaš, Serbia (RMS, YU-010, 851)

$\begin{array}{lllll}\text { vo mekla } & \text { kado } & \text { xabe } & \text { pala tute } \\ \text { he leave.PST.3SG } & \text { this.M } & \text { food } & \text { for 2SG.LOC } \\ \text { thaj pala } & \text { čjire } & \text { phrala } & \\ \text { and for } & \text { your.PL } & \text { brother.PL }\end{array}$

In most dialects, the R-like argument used for source is generally expressed with the ablative case; see example in (68a). Lithuanian Romani is an exception: the locative case is used, as in (68b), sometimes in variation with the ablative which is currently being replaced by the locative more generally (see Tenser 2005 for more details; see Matras 1999a on a comparable development in the Polska Roma dialect).

(68) 'I got these flowers from my sister.'

(a) Sinti, Romania (RMS, RO-065, 479)

kae bluma jom fun $\mathrm{mr}$ phenjatar

DEM.PL flower.PL take.PST.1SG from my sister.OBL.F.ABL

(b) Lithuanian Romani, Lithuania (RMS, LT-005, 479)

$\begin{array}{llllll}\text { mə lyjom } & \text { da } & \text { kvjaty } & \text { mre } & \text { pxenjate } \\ \text { I } & \text { take.PST.1SG } & \text { DEM } & \text { flower.PL } & \text { my.OBL } & \text { sister.OBL.F.LOC }\end{array}$

The Romani comitative marker encoding accompaniment, and the instrumental marker, encoding the instrument used for an action, are the same, as in other European language (see Stolz, Stroh, and Urdze 2013, WALS 52). Example in (69) illustrates the use of a 
comitative, relying on the instrumental case marker $-c a$, and example in (70) illustrates the use of an instrumental, with the same case.

(69) Central Slovak Romani, Slovakia (RMS, SK-031, 483)

geljom ando foro mire duje phralenca

went.1SG in.M town my.OBL.PL two.OBL brother.OBL.PL.INS

'I went to town with my two brothers.'

(70) Central Slovak Romani, Slovakia (RMS, SK-031, 777)

murdardža kaxnja čuraha

kill.PST.3SG chicken.OBL.F knife.OBL.F.INS

'He killed the chicken with a knife.'

For clausal possession, Romani uses the verb 'to be' and encodes the possessor in the oblique; see examples in (71) (for adnominal possession see section 2). This is most likely a relic of the genitive origin of the oblique case in Middle Indo-Aryan. In Balkan dialects of Romani, the possessor in the oblique case may be reduplicated; see an example from Arli in (71a).

(71) 'She has a brother.'

(a) Arli, Macedonia (RMS, MK-003, 976)

ła isi ła phrał

she.OBL is she.OBL brother 
(b) Kalderaš, Serbia (RMS, YU-010, 976)

la si phral

she.OBL is brother

(c) East Slovak, Slovakia (RMS, SK-011, 976)

la hin phral

she.OBL is brother

(d) Polska Roma, Poland (RMS, PL-018, 976)

ła hi phal

she.OBL is brother

'External possession' refers to cases where the possessor is external to the noun phrase that contains the possessed. Proto-Romani most likely had an external possessor construction marked by the independent oblique. This construction has been preserved in most Romani dialects, as can be seen in the examples of inalienable possession in the samples from Kalderaš, Slovak Romani, Polish Romani and Sinti from Romania, in (72). Crevels and Bakker (2000) note that some dialects follow case marking from their contact languages. For example, Russian Roma use the locative case and Latvian Romani uses the dative; see (72f) and (72g) respectively. Finally, Arli illustrates a case of so-called internal possession, (72a).

(72) 'My nose hurts.'

Arli, Macedonia (RMS, MK-002, 982) 
mo nak dukhala

my.M nose hurt.3SG

(b) Kalderaš, Serbia (RMS, YU-010, 982)

man dukhal o nak

me.OBL hurt.3SG DEF.NOM.M nose

(c) East Slovak, Slovakia (RMS, SK-011, 982)

dukhal man o nakh

hurt.3SG me.OBL DEF.NOM.M nose

(d) Polska Roma, Poland (RMS, PL-018, 982)

man dukhał nakh

me.OBL hurt.3SG nose

(e) Sinti, Romania (RMS, RO-022, 982)

dukhal man u nak

hurt.3SG me.OBL DEF.NOM.M nose

(f) Russian Roma, Russia (RMS, RUS-003, 982)

mande dukxal o nak

me.LOC hurt.3SG DEF.NOM.M nose 
(g) Latvian Romani, Latvia (RMS, LV-006, 982)

mange dukxala nakx

me.DAT hurt.3SG nose

Experiencer verbs frequently function differently to other transitive verbs (see

Verhoeven 2010). Example (73) illustrates the coding of an experiencer as an indirect object with a dative.

(73) East Slovak, Slovakia (RMS, SK-011, 993)

kampol mange mire kamaraden

like.3SG me.DAT my.PL friends.OBL.PL

'I like my friends.'

Stative predicates are marked in the nominative case:

(74) Kalderaš, Serbia (RMS, YU-010, 988)

vo si rašaj

he.NOM is.3SG priest.NOM.SG.M

'He is a priest.'

In sum, nominative case is the least complex case and serves to encode subjects, inanimate patient-like arguments (objects), possessees, and stative predicatives. Possessors, clausal and external, and animate patient-like arguments are marked by the independent oblique (or accusative) case. The independent oblique can also be used in some dialects for recipient-like arguments, in variation with the dative. Dative case is 
also used for the experiencer, together with the oblique case. Genitive case is used for adnominal possessors. The comitative and instrumental roles are coded by the instrumental case, without any adpositions. Source is encoded by the ablative case, sometimes in combination with an adposition. The benefactive role is generally encoded by an adposition and dative case.

\subsection{Local relations}

Localisation may be encoded in adpositional NPs or on locational NPs, without the use of an adposition, through case marking on the noun. The factors that determine this choice depend on prominence hierarchies involving animacy, definiteness, referentiality, lexicality, etc. Non-separative inessive localisation ('in, into') is coded by the nominative and the locative case; see example in (75). Locative case may also code non-separative contact relations ('on').

(75) Sofia Erli, Bulgaria (RMS, BG-024, 917)

$\begin{array}{lllll}\text { oj } & \text { phiravel } & \text { e } & \text { čhaves } & \text { vastende } \\ \text { she } & \text { carries.3SG } & \text { DEF.OBL.M } & \text { child.OBL.M } & \text { arm.OBL.PL.LOC }\end{array}$

'She carries the child in her arms.'

In contrast, the ablative case codes separative localisations, e.g., 'out of', 'from', 'from the top of', and a number of peripheral localisations, e.g., 'across, over', 'around', 'through', 'by'.

The dative case encodes the directive adessive, 'to, toward'. The instrumental case encodes the perlative, 'through', in particular in dialects that are in contact with 
Slavic. In the Central Romani dialects, instrumental may also code the sequentive 'along'.

In most adpositional NPs, we note variation between the use of nominative case, and oblique cases such as locative, accusative, or ablative case (for further details on 'nominative vs. oblique split' see Elšik and Matras 2006, p.247). The choice between these cases depends on prominence hierarchies: oblique cases are preferred with pronouns.

Several South Balkan dialects have developed a general local adposition from the adessive ke/te that combines with a more specialized adposition. These complex adpositions generally combine with the nominative case, whereas the simple adpositions combine with the oblique cases.

\subsection{Temporal relations}

Simultaneous temporal relations are coded through a variety of means depending on individual dialects, e.g., for clock time, locative case is used in Kalajdži efta saxatende 'at 7 o'clock' (RMS, BG-007), the ablative case in East Slovak Romani efta orendar 'at 7 o'clock' (RMS, SK-011), and the adessive ke/te adposition with nominative case in Sofia Erli ko efta o sahati 'at 7 o'clock' (RMS, BG-024).

Posterior-durative relations, 'since', are coded through ablative case in Finnish Romani, e.g., niijalko čhoones-ta 'since June' (RMS, FIN-008, 458) as well as in the Northeastern Romani dialects and most Central dialects, whereas several other dialects rely on the adposition katar/tar 'from', e.g., tar o juni 'since June', in Arli (RMS, MK$003,458)$. 
Anterior-durative relations, 'until', are coded by the adessive ke/te, e.g., ko lynaj 'until the summer' in Russian Romani (RMS, RUS-003, 453), or by ke/te in combination with a limitative particle, e.g., ži ko nilaj 'until the summer' in Romungro from Romania (RMS, RO-001, 453). More rarely, the inessive may be used, e.g., $\check{z} i$ ando verano 'until the summer' in Mexican Vlax (RMS, MX-001, 453), dži andro ljinaj 'until the summer' in East Slovak Romani (RMS, SK-011, 453).

Finally, anterior and posterior sequence relations, 'before' and 'after', are coded through the spatial adpositions angle/anglal and pal/palal respectively.

\section{Conclusion}

In this chapter we presented an overview of selected syntactic-typological features of Romani. We showed that Romani, an Indic language, exhibits a number of features that have been shaped through contact with non-Indic languages during the past millennium. For example, Romani exhibits nominative-accusative and neutral case alignment, whereas morphological ergative alignment is found in many Indic languages and can be reconstructed for Proto-Romani (Bubeník 2000; Matras 2002).

Innovations of the Early Romani period, through intensive contact with Byzantine Greek, include grammaticalization of a definite article (a unique feature among New Indo-Aryan languages); use of the resumptive relativization strategy and of interrogatives as relativizers; factuality distinction in subordinate clauses; changes in word order, i.e., VS used as a connective-narrative order, and SV as a contrastivethematic order; emergence of a dominant $\mathrm{VO}$ order following a change from a dominant OV order (OV order is still encountered in Indic languages, see Dryer 2013, WALS 83). 
In accordance with cross-linguistic tendencies associated with a VO order, Romani dialects have prepositions (an innovative feature from a New Indo-Aryan perspective where postpositions are common) and a dominant ADJ-N order in NPs, the adjective preceding the noun (an order that is more frequently associated with OV languages) (Dryer 2013, WALS 95, 96, 97). In addition, relative clauses are postnominal (NREL), a feature which is cross-linguistically common, but tends to be absent in Indic languages where the relative clause precedes the noun (RELN) (Dryer 2013, WALS 90). Interestingly, Romani has kept dependent marking in possessive noun phrases, a dominant feature of the languages of India (Nichols and Bickel 2013, WALS 24). The Romani genitive noun phrase precedes the head noun, an order that is rare in European languages but predominant in India (Dryer 2013, WALS 86).

The migration of the Romani-speaking populations beyond the Balkans led to the split of Romani into contemporary dialects. Contact with a number of different languages shaped the typological features of particular Romani varieties, leading, for example, to the emergence of new infinitives in some dialects, and the loss of definite articles or gender distinction in others.

Romani is of interest to typologists as it illustrates the significance of the geographical distribution of typological features over genetic affiliation at two levels: First, through the emergence of a number of shared innovations in contact with Byzantine Greek, which changed the typological profile of Romani in comparison to the other Indo-Aryan languages. Second, through dialect-specific innovations which emerged following contact with different European languages. 
Abbreviations

Glosses following the Leipzig Glossing Rules as expanded within the project "Designing Spoken corpora for Cross-linguistic Research" (funded by the French National Research Agency).

A agent-like argument, ABL ablative, ACC accusative, ADJ adjective, ART article, COMP complementizer, COND conditional, CORR correlative particle, DAT dative, DEF definite article, DEM demonstrative, DO direct object, F feminine, FUT future, IO indirect object, INDF indefinite, INF infinitive, INS instrumental, GEN genitive, GER gerund, LOC locative, M masculine, $\mathrm{N}$ noun, NEG negative, NOM nominative, NP noun phrase, NUM numeral, QNT quantifier, O object, OBL oblique, P patient-like argument, PL plural, PST past, PTCP participle, R recipient-like argument, REFL reflexive, REL relative pronoun, REM remote, $\mathrm{S}$ single argument, $\mathrm{SBJV}$ subjunctive, $\mathrm{SG}$ singular, $\mathrm{T}$ theme argument, V verb, VOC vocative.

Database abbreviations

AL Albania, BG Bulgaria, CZ Czech Republic, FIN Finland, GR Greece, HU Hungary, LT Lithuania, LV Latvia, MK Republic of North Macedonia, MX Mexico, PL Poland, RMS Romani Morpho-Syntax database, RO Romania, RUS Russia, SK Slovakia, Txt text, UKR Ukraine, WALS World Atlas of Language Structures, YU Yugoslavia 
References

Adamou, Evangelia. 2013. Replicating Spanish estar in Mexican Romani. Linguistics. 51(6):1075-1105.

Adamou, Evangelia. 2016. A corpus-driven approach to language contact. Endangered languages in a comparative perspective. Boston and Berlin: Mouton de Gruyter.

Alexopoulou, Theodora. 2006. Resumption in relative clauses. Natural language and linguistic theory. 24(1):57-111.

Andrews, Avery D. 2007. Relative clauses. In: Shopen, Timothy, ed. Language typology and syntactic description. Cambridge: Cambridge University Press. 206236.

Arvaniti, Amalia, and Adamou, Evangelia. 2011. Focus expression in Romani. In: Byram Washburn, Mary, McKinney-Bock, Katherine, Varis, Erika, Sawyer, Ann, and Tomaszewicz, Barbara, eds. Proceedings of the 28th west coast conference on formal linguistics. Somerville, MA: Cascadilla Proceedings Project. 240-248.

Benišek, Michael. 2017. Eastern Uzh varieties of North Central Romani. Unpublished $\mathrm{PhD}$ thesis, Charles University of Prague.

Bodnárová, Zuzana. 2015. Vend Romani: A grammatical description and sociolinguistic situation of the so-called Vend dialects of Hungary. Unpublished $\mathrm{PhD}$ thesis, Charles University of Prague.

Boretzky, Norbert. 1993a. Bugurdži. Deskriptiver und historischer Abriß eines Romani Dialekts. Wiesbaden: Harrassowitz.

Boretzky, Norbert. 1993b. Conditional sentences in Romani. Sprachtypologie und Universalienforschung. 46:83-99. 
Boretzky, Norbert. 1996a. The 'new infinitive' in Romani. Journal of the Gypsy Lore Society. Fifth series. 6:1-51.

Boretzky, Norbert. 1996b. Entlehnte Wortstellungssyntax im Romani. In: Boretzky, Norbert, Enninger, Werner, and Stolz, Thomas, eds. Beiträge zum 10. Bochum: Brockmeyer. 95-121.

Boretzky, Norbert. 1998. Erli. Eine Bestandsaufnahme nach den Texte von GilliatSmith. Studii Romani. 5-6: 122-160.

Bubeník, Vít. 1997. Object doubling in Romani and the Balkan languages. In: Matras, Yaron, Bakker, Peter, and Kyuchukov, Hristo, eds. The typology and dialectology of Romani. Amsterdam: John Benjamins. 95-106.

Bubeník, Vít. 2000. Was Proto-Romani an ergative language? In: Elšík, Viktor, and Matras, Yaron, eds. Grammatical relations in Romani. The noun phrase. Amsterdam: John Benjamins. 205-227.

Cech, Petra, and Heinschink, Mozes F. 1999. Sepečides-Romani. Grammatik, Texte und Glossar eines türkischen Romani-Dialekts. Wiesbaden: Harrassowitz.

Comrie, Bernard. 2013. Alignment of case marking of full noun phrases. In: Dryer, Matthew S., and Haspelmath, Martin, eds. The world atlas of language structures online. Leipzig: Max Planck Institute for Evolutionary Anthropology. (Available online at http://wals.info/chapter/98, Accessed on 2017-07-25.)

Corbett, Greville G. 2013. Number of genders. In: Dryer, Matthew S., and Haspelmath, Martin, eds. The world atlas of language structures online. Leipzig: Max Planck Institute for Evolutionary Anthropology. (Available online at http://wals.info/chapter/30, Accessed on 2017-07-25.) 
Crevels, Mily, and Bakker, Peter. 2000. External possession in Romani. In: Elšík, Viktor, and Matras, Yaron, eds. Grammatical relations in Romani. The noun phrase. Amsterdam: John Benjamins. 151-185.

Cristofaro, Sonia. 2013. Utterance complement clauses. In: Dryer, Matthew S., and Haspelmath, Martin, eds. The world atlas of language structures online. Leipzig: Max Planck Institute for Evolutionary Anthropology.

(Available online at http://wals.info/chapter/128, Accessed on 2017-07-25.)

Dixon, Robert M. W. 2010. Basic linguistic theory. Oxford: Oxford University Press.

Dryer, Matthew S. 2013. Order of object and verb. In: Dryer, Matthew S. and Haspelmath, Martin, eds. The world atlas of language structures online. Leipzig: Max Planck Institute for Evolutionary Anthropology.

(Available online at http://wals.info/chapter/83, Accessed on 2017-07-25.)

Dryer, Matthew S. 2013. Order of genitive and noun. In: Dryer, Matthew S. and Haspelmath, Martin, eds. The world atlas of language structures online. Leipzig: Max Planck Institute for Evolutionary Anthropology. (Available online at http://wals.info/chapter/86, Accessed on 2017-07-25.)

Dryer, Matthew S. 2013. Order of relative clause and noun. In: Dryer, Matthew S., and Haspelmath, Martin, eds. The world atlas of language structures online. Leipzig: Max Planck Institute for Evolutionary Anthropology. (Available online at http://wals.info/chapter/90, Accessed on 2017-07-25.)

Dryer, Matthew S. 2013. Relationship between the order of object and verb and the order of adposition and noun phrase. In: Dryer, Matthew S., and Haspelmath, Martin, eds. The world atlas of language structures online. Leipzig: Max Planck Institute for Evolutionary Anthropology. (Available online at http://wals.info/chapter/95, Accessed on 2017-07-25.) 
Dryer, Matthew S. 2013. Relationship between the order of object and verb and the order of relative clause and noun. In: Dryer, Matthew S., and Haspelmath, Martin, eds. The world atlas of language structures online. Leipzig: Max Planck Institute for Evolutionary Anthropology.

(Available online at http://wals.info/chapter/96, Accessed on 2017-07-25.)

Dryer, Matthew S. 2013. Relationship between the order of object and verb and the order of adjective and noun. In: Dryer, Matthew S., and Haspelmath, Martin, eds. The world atlas of language structures online. Leipzig: Max Planck Institute for Evolutionary Anthropology.

(Available online at http://wals.info/chapter/97, Accessed on 2017-07-25.)

Elšík, Viktor. 2000. Inherited indefinites in Romani. Paper presented at the Fifth International Conference on Romani Linguistics, Sofia, 14-17 September 2000.

Elšík, Viktor, and Matras, Yaron. 2006. Markedness and language change. Berlin: Mouton de Gruyter.

Elšík, Viktor, and Matras, Yaron. 2009. Modality in Romani. In: Hansen, Björn, and de Haan, Ferdinand, eds. Modals in the languages of Europe. Berlin: Mouton de Gruyter. 267-324.

Friedman, Victor A. 1985. Balkan Romani modality and other Balkan languages. Folia Slavica. 7: 381-389.

Friedman, Victor A. 2000. Proleptic and resumptive object pronouns in Romani: a Balkan noun phrase perspective. In: Elšík, Viktor, and Matras, Yaron, eds. Grammatical relations in Romani. The noun phrase. Amsterdam: John Benjamins. 187-204.

Friedman, Victor A. 2001. The Romani indefinite article in its historical and areal context. In: Igla, Birgit, and Stolz, Thomas, eds. Was ich noch sagen wollte... A 
multilingual festschrift for Norbert Boretzky. Sprachtypologie und Universalienforschung, Beihefte, Studia typologica 2. Berlin: Akademie Verlag. 287-301.

Haig, Geoffrey, and Schnell, Stefan. 2016. The discourse basis of ergativity revisited. Language. 92(3):591-618.

Holzinger, Daniel. 1993. Das Rómanes. Grammatik und Diskursanalyse der Sprache der Sinte. Innsbruck: Verlag des Instituts für Sprachwissenschaft der Universität Innsbruck.

Iggesen, Oliver A. 2013. Number of cases. In: Dryer, Matthew S., and Haspelmath, Martin, eds. The world atlas of language structures online. Leipzig: Max Planck Institute for Evolutionary Anthropology.

(Available online at http://wals.info/chapter/49, Accessed on 2017-07-25.)

Igla, Birgit. 1996. Das Romani von Ajia Varvara. Deskriptive und historischvergleichende Darstellung eines Zigeunerdialekts. Wiesbaden: Harrassowitz.

Keenan, Edward, and Comrie, Bernard. 1977. Noun phrase accessibility and universal grammar. Linguistic Inquiry. 8:63-99.

Kolliakou, Dimitra. 2004. Monadic definites and polydefinites: Their form, meaning and use. Journal of Linguistics. 40:263-333.

Koptjevskaja-Tamm, Maria. 2000. Romani genitives in cross-linguistic perspective. In: Elšík, Viktor, and Matras, Yaron, eds. Grammatical relations in Romani. The noun phrase. Amsterdam: John Benjamins. 123-149.

Leggio, Viktor D. 2011. The dialect of the Mitrovica Roma. Romani Studies. Fifth series. 21(1):57-113.

Leggio, Viktor D., and Matras, Yaron. 2017. Variation and dialect levelling in the Romani dialect of Ţăndărei. Romani Studies. Fifth series. 27(2):173-209. 
Malchukov, Andrej, Haspelmath, Martin, and Comrie, Bernard. 2010. Ditransitive constructions: a typological overview. In: Malchukov, Andrej, Haspelmath, Martin, and Comrie, Bernard, eds. Studies in ditransitive constructions: A comparative handbook. Berlin and New York: Mouton de Gruyter. 1-64.

Matras, Yaron. 1994. Untersuchungen zu Grammatik und Diskurs des Romanes. Dialekt der Kelderaša/Lovara. Wiesbaden: Harrassowitz.

Matras, Yaron. 1995. Connective (VS) word order in Romani. Sprachtypologie und Universalienforschung. 48:189-203.

Matras, Yaron. 1999a. The speech of the Polska Roma: some highlighted features and their implications for Romani dialectology. Journal of the Gypsy Lore Society. Fifth series. 9(1):1-28.

Matras, Yaron. 1999b. Subject clitics in Sinti. Acta Linguistica Academiae Scientiarum Hungaricae. 46:147-69.

Matras, Yaron. 2002. Romani: a linguistic introduction. Cambridge: Cambridge University Press.

Matras, Yaron, and Tenser, Anton. 2016. Complementizers in Romani. In: Boye, Kasper, and Kehayov, Petar, eds. Complementizer semantics in European languages. Berlin: Mouton de Gruyter. 341-375.

Nichols, Johanna, and Bickel, Balthasar. 2013. Locus of marking in possessive noun phrases. In: Dryer, Matthew S., and Haspelmath, Martin, eds. The world atlas of language structures online. Leipzig: Max Planck Institute for Evolutionary Anthropology. (Available online at http://wals.info/chapter/24, Accessed on 2017-07-25.) 
Payne, John. 1995. Inflecting postpositions in Indic and Kashmiri. In: Plank, Frans, ed. Double case: Agreement by Suffixaufnahme. New York and Oxford: Oxford University Press. 283-298.

Plank, Frans. 1995. (Re-)Introducing Suffixaufnahme. In: Plank, Frans, ed. Double case: Agreement by Suffixaufnahme. New York and Oxford: Oxford University Press Oxford. 3-110.

Rusakov, Alexandr, and Abramenko, Olga. 1998. North Russian Romani dialect: Intereference in case system. Grazer Linguistische Studien. 50:109-133.

Sampson, John. 1926 (1968). The dialect of the Gypsies of Wales, being the older form of British Romani preserved in the speech of the clan of Abram Wood. Oxford: Clarendon Press.

Sasse, Hans-Jürgen. 1995. 'Theticity' and VS order: A case study. Sprachtypologie und Universalienforschung. 48:3-31.

Stolz, Thomas, Stroh, Cornelia, and Urdze, Aina. 2013. Comitatives and instrumentals. In: Dryer, Matthew S., and Haspelmath, Martin, eds. The world atlas of language structures online. Leipzig: Max Planck Institute for Evolutionary Anthropology. (Available online at http://wals.info/chapter/52, Accessed on 2017-07-25.)

Tenser, Anton. 2005. Lithuanian Romani. Munich: Lincom Europa.

Tenser, Anton. 2008. Northeastern group of Romani dialects. Unpublished PhD thesis. University of Manchester.

Tenser, Anton. 2016. Semantic map borrowing - case representation in Northeastern Romani dialects. Journal of Language Contact. 9:211-245.

Verhoeven, Elisabeth. 2010. Agentivity and stativity in experiencer verbs: Implications for a typology of verb classes. Linguistic Typology. 14:213-251. 
Wogg, Michael, and Halwachs, Dieter W. 1998. Syntax des Roman. Oberwart: Verein Roma.

${ }^{1}$ Accessed at http://romani.humanities.manchester.ac.uk/rms/. Viktor Elšík \& Yaron Matras 2001-present. Current version supported by Christopher White, Charlotte Jones, and Christa Schubert. 